Research Article Evolutionary Genetics

\title{
Cryptic diversity and diversification processes in three cis-Andean Rhamdia species (Siluriformes: Heptapteridae) revealed by DNA barcoding
}

\author{
Josiane Ribolli $^{1^{*}}$ (D), Evoy Zaniboni Filho ${ }^{1^{*}}$, Bianca Maria Soares Scaranto ${ }^{1}$, Oscar Akio Shibatta ${ }^{2}$ (D) \\ and Carolina Barros Machado ${ }^{3}$ (1) \\ ${ }^{1}$ Universidade Federal de Santa Catarina, Departamento de Aquicultura, Lagoa do Peri, Laboratório de \\ Biologia e Cultivo de Peixes de Água Doce, Florianópolis, SC, Brazil. \\ ${ }^{2}$ Universidade Estadual de Londrina, Departamento de Biologia Animal e Vegetal, Centro de Ciências \\ Biológicas, Londrina, PR, Brazil. \\ ${ }^{3}$ Universidade Federal de São Carlos, Departamento de Genética e Evolução, São Carlos, SP, Brazil.
}

\begin{abstract}
The wide distribution of the Neotropical freshwater catfish Rhamdia offers an excellent opportunity to investigate the historical processes responsible for modeling South America's hydrogeological structure. We used sequences from cis-Andean and Mesoamerican Rhamdia species to reconstruct and estimate divergence times among cis-Andean lineages, correlating the results with known geological events. Species delimitation methods based on distance (DNA barcoding and BIN) and coalescence (GMYC) approaches identified nine well-supported lineages from the cis-Andean region from sequences available in the BOLD dataset. The cis-Andean Rhamdia lineages diversification process began in Eocene and represented the split between cis-Andean and Mesoamerican clades. The cis-Andean clade contains two principal groups: Northwest clade (MOTUs from Amazon, Essequibo, Paraguay, and Itapecuru basins) and Southeast clade (Eastern Brazilian shield basins (Paraná, Uruguay, Iguaçu, and São Francisco) plus eastern coastal basins). The diversification of the cis-Andean Rhamdia lineages results from vicariance and geodispersion events, which played a key role in the current intricate distribution pattern of the Rhamdia lineages. The wide geographical distribution and large size of the specimens make it attractive to cultivate in different countries of the Neotropical region. The lineages delimitation minimizes identification mistakes, unintentional crossings by aquaculture, and reduces natural stocks contamination.
\end{abstract}

Keywords: Aquaculture, freshwater fishes, marine transgression/regression, phylogeography, underestimated diversity.

Received: December 21, 2020; Accepted: April 07, 2021.

\section{Introduction}

Neotropical freshwater fishes constitute a host of global biodiversity (Albert et al., 2020), and more recent surveys have described at least 6,080 species (Dagosta and de Pinna, 2019). However, there is a consensus that this number is underestimated, with innumerable new species being described each year (Reis et al., 2016; Dagosta and de Pinna, 2019). The vast Neotropical environments allow ecological species adaptations (Cooke et al., 2012), which when they occur widely and in different habitats (e.g., large and rushing rivers, caves, lakes, ponds, and streams) make it difficult to carry out a broad sampling, thus contributing to hiding species that were historically identified and delimited only by traditional taxonomy (Melo et al., 2016). Beyond this enormous habitat variety, phenotypic plasticity and cryptic species' occurrence are the main reasons for these underestimating (Bickford et al., 2007).

The correct species identification is essential for different areas, such as aquaculture, biodiversity conservation,

Send correspondence to Josiane Ribolli. Universidade Federal de Santa Catarina, Departamento de Aquicultura, Lagoa do Peri, Laboratório de Biologia e Cultivo de Peixes de Água Doce, Rodovia SC 406-Km3, 3532, CEP 88066-260, Lagoa do Peri, Florianópolis, SC, Brazil. E-mail: josianeribolli @gmail.com.

${ }^{*}$ These authors contributed equally to the article. biogeography, ecology, comparative biology, and systematics (e.g. Agapow et al., 2004; Bortolus, 2008; Maclaurin and Sterelny, 2008; Frankham et al., 2012; Scaranto et al., 2018). DNA barcoding is a molecular tool widely used to delimitate and identify cryptic species in the most varied taxonomic groups (Hebert et al., 2003; Hebert et al., 2004). An alternative approach to practical help correctly identifies the species when morphological traits are insufficient. This method, associated with a quantitative species delimitation approach (GMYC Pons et al., 2006; Fujisawa and Barraclough, 2013), have been employed with success in the vast number of Neotropical fish species (Pereira et al., 2013; Machado et al., 2017; Ramirez et al., 2017). This approach allows the identification of Operational Molecular Taxonomy Units (hereafter named MOTUs) and species resolution with precision (Machado et al., 2017; Melo et al., 2018).

Rhamdia is an emblematic genus with an intriguing taxonomic scenario and species delimitation issues (Albert et al., 2020; Ríos et al., 2020). In Brazil's southern region, there is a great interest in the commercial cultivation of Rhamdia quelen (Battisti et al., 2020). Its broad geographical distribution and low temperatures tolerance make it attractive to cultivate in different parts of the Neotropical region, especially in Southern Brazil, Uruguay and Argentina (Salhia et al., 2008; Gomes et al., 2000; Ittzéz et al., 2020). Thus, it is necessary to identify the species to avoid unintentional crossings (Scaranto et al., 
2018). More recently, some synonyms of $R$. quelen were recovered with integrative methods (Garavello and Shibatta, 2016; Ribolli et al., 2017), new species were described (DoNascimiento et al., 2004; Bichuette and Trajano, 2005; Angrizani and Malabarba, 2018), flagging Rhamdia quelen as a species complex. Koerber and Reis (2020) suggested a new type-locality in an affluent of the Guanabara Bay, state of Rio de Janeiro, to replace a missing type specimen of Rhamdia quelen. However, a taxonomic revision of Rhamdia is straightaway necessary to explain species delimitation problems, which hinder their correct identification (Koerber and Reis, 2020). Because Rhamdia species occur in almost every freshwater environment of the Neotropical region, an accurate dataset (e.g., BOLD system database) helps understand its distribution. Therefore, precise information on how Rhamdia lineages is distributed in the main geographic basins of the cis-Andean region offers an excellent opportunity to investigate the historical processes responsible for modeling the hydrogeological structure of South America, and will contribute to studies on the identification of lineages and species that still make up the Rhamdia quelen species complex.

In this study, we used species delimitation methods based on distance (DNA barcoding and BIN), and coalescence (GMYC) approaches to identify genetic units of three Rhamdia species from the cis-Andean region. The aim is to point out the independent evolutionary lineages flagging potentially undescribed taxa. Although we are aware of the limitations to create biogeographic hypotheses based on single-locus, we also investigated which historical events were responsible for diversification processes of Rhamdia lineages. Based on the evolution of modern drainage systems and biogeographic history of Neotropical freshwater fish species from the major basins of South America (e.g., Montoya-Burgos, 2003; Hubert and Renno, 2006; Ramirez et al., 2017), we expect that vicariance and geodispersion events were driven diversification processes.

\section{Material and Methods}

\section{Sampling}

Fin clips of 36 specimens morphologically identified as Rhamdia quelen complex, Rhamdia branneri, and Rhamdia voulezi were sampled from 2014 to 2018. Specimens were collected from the Uruguay, Benedito Novo and Itapocu rivers, and Peri Lagoon, because this species are important as aquaculture resource in this region. Tissue samples were preserved in $95 \%$ ethanol and stored at $-20{ }^{\circ} \mathrm{C}$. Individuals sampled were photographed, stored in the collection of the Laboratório de Biologia e Cultivo de Peixes de Água Doce (LAPAD/UFSC), Santa Catarina State, Brazil. Collecting license was provided by Instituto Brasileiro do Meio Ambiente e dos Recursos Naturais Renováveis - IBAMA (16/2011 and $659 / 2015)$. Vouchers were deposited in the ichthyological collection of the Museu de Zoologia of the Universidade Estadual de Londrina (MZUEL).

We also included 63 barcodes of Rhamdia genus from the cis-Andean region, corresponding to Itapecuru, Paraná, Mucuri, Essequibo, Paraguay, Paraíba do Sul, São Francisco, and Ucayali basins; four sequences of $R$. laticauda from Nicaragua and Panama; eight sequences of $R$. quelen from
Panama and Nicaragua (code BSFFA) and three sequences of $R$. guatemalensis from Mexico (code HBGM), both from the Mesoamerican region; and one sequence of Pimelodella sp. as outgroup were downloaded from Barcode of Life Database (BOLD; www.boldsystems.org). We used exclusively (except the Paraguay River basin samples from Genbank) sequences from the BOLD system because this database is accurate and allows verification of the sequences' quality (trace files). Because Rhamdia is widely distributed, we took care to evaluate all available sequences, reducing the mistakes that may be associated with public and non-generated sequences; as such, we do not use most Genbank and some BOLD sequences. Details like voucher number, locality information, and accession numbers for databases are shown in Supplementary Table S1. Our final dataset for species delimitation and phylogeographic analyses was composed of 115 specimens distributed for all South America (Figure 1 and Table S1).

\section{DNA amplification and sequencing}

Rhamdia specimens' DNA was extracted from caudal fin fragments using a salt method (Aljanabi and Martinez, 1997). COI fragments were amplified by polymerase chain reaction (PCR) using primers FishF1 and FishR1 (Ward et al., 2005), according to Bellafronte et al. (2013). After confirming amplification in a $1 \%$ agarose gel, the PCR products were purified with $20 \%$ PEG (Lis, 1980). Sequencing reactions were performed using BigDye TM Terminator v 3.1 (Cycle Sequencing Ready Reaction Kit, Applied Biosystems), and fragments were sequenced in ABI 3500XL (Applied Biosystems). All sequences were deposited in BOLD (accession numbers are given in Table $\mathrm{S} 1$ - PBRH code).

\section{Data analysis}

The sequences were aligned, using the Clustal W algorithm, and edited in Geneious R7 6.1.6 (http://www. geneious.com, Kearse et al., 2012). As mentioned, we also combined sequences available in the BOLD system (http:// www.boldsystems.org): cis-Andean Rhamdia specimens (codes FARG, LARI, FPSR, MUCU, BSB, FUPR, ITAPE, PBRH, BSFFA, ANGBF, and HBGM), Mesoamerican Rhamdia specimens (codes HBGM and TZGAA), Pimelodella sp. (code HM) as the outgroup, and six Rhamdia sequences available in Genbank (code KU).

Because of the uncertain taxonomic validity of Rhamdia species, mainly $R$. quelen complex, we used a phylogenetic General Mixed Yule Coalescent (GMYC) approach based on single-locus data to estimate the MOTUs in the present dataset. An ultrametric gene tree required by the analysis was generated in BEAST v.2.5.2 (Bouckaert et al., 2014), with $\mathrm{HKY}+\mathrm{G}$ substitution model calculated in the jModelTest 2.1.4 (Darriba et al., 2012) using the Bayesian Information Criterion, relaxed molecular clock with a lognormal distribution, and Birth and Death model as tree prior. The other priors used in this analysis were kept in default. Three independent runs were carried out with 50 million generations each. All runs were combined using LogCombiner v.2.5.2, and $25 \%$ of the generations were discarded as burn-in. The posterior sample of trees was summarized in the TreeAnnotator to produce a maximum clade credibility tree. The effective sample size for 


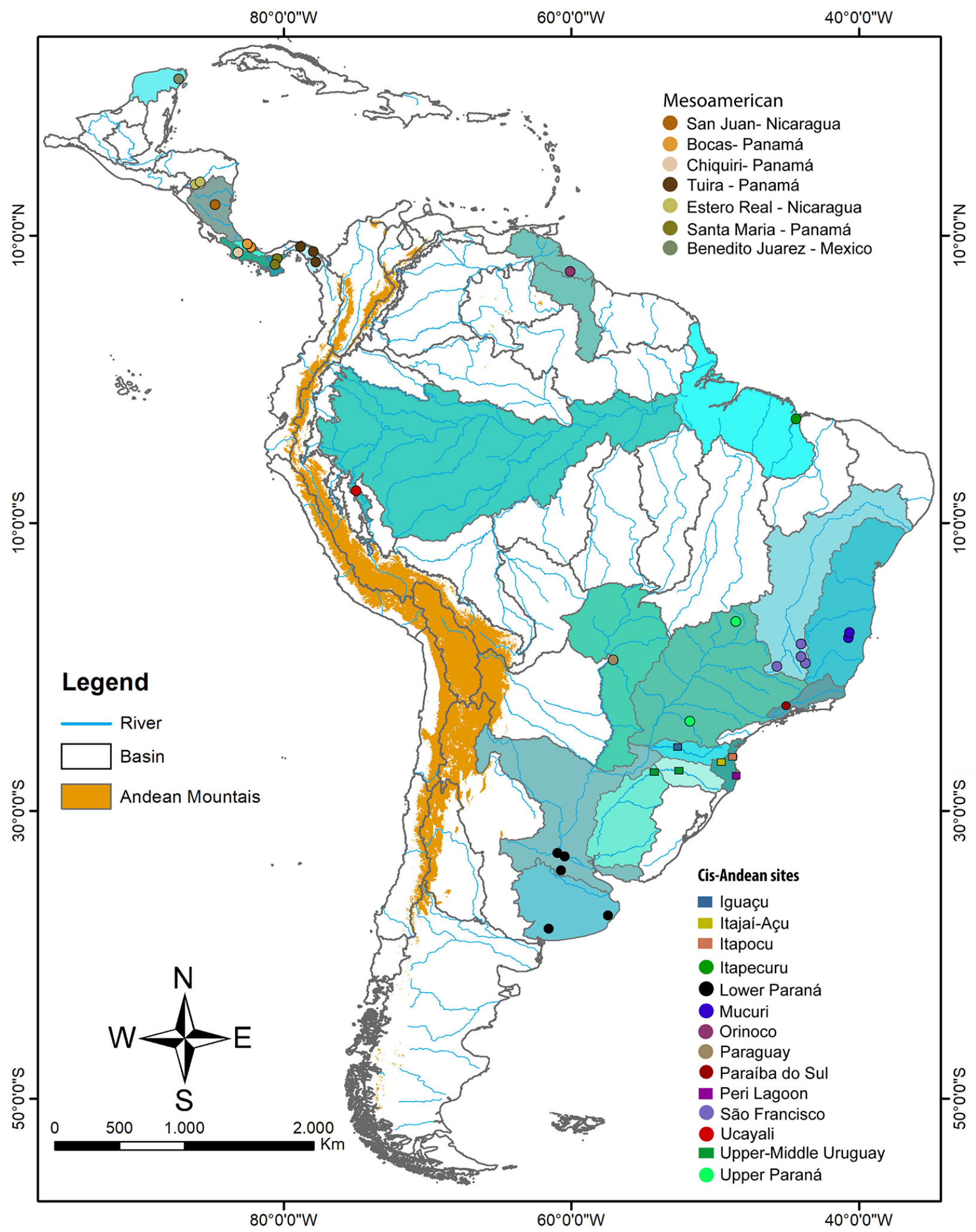

Figure 1 - Sampling sites of Rhamdia species in South America. Circles represent samples from BOLD System (http://www.boldsystems.org/), while squares are sequences obtained in this study. Colors indicated the hydrographic basin where collected.

all parameters (ESS) was verified in Tracer v1.5 (Rambaut and Drummond, 2007). GMYC analysis was carried out in SPLITs (SPecies Limits by Threshold Statistics; Monaghan et al., 2009) package with RStudio (http://r-forge.r-project. org/ projects/ splits), using the unique threshold method to detect the transition point between intra- and interspecific relationships.

We also employed a distance approach to determine the MOTUs present in our dataset (DNA barcoding methodology - Hebert et al., 2003). According to this method, sequences 
from the same species show low genetic distance than the sequences from different species given a threshold. Because we are focused on determining the lineages from the cis-Andean region, we estimated an optimum threshold (OT) for this specific dataset. To establish the OT, we used the localMimima function from the SPIDER package (SPecies IDentity and Evolution in R, Brown et al., 2012) in the R platform. This function is based on the concept of the barcoding gap (Hebert et al., 2003) and used a Kimura 2-Parameter (K2P) distance matrix to find the transition between intra- and interspecific distances. The method does not require a priori information about taxon identity. After the OT was determined, we used jMOTU (Jones et al., 2011) to obtain the MOTUs. We also employed the Barcode Index Number system (BIN Ratnasingham and Hebert, 2013), an online framework based on the distance that cluster barcode sequences algorithmically.

It is possible to find incongruous results among methods because they employ distinct algorithms (Ramirez et al., 2020). Thus, the final adopted species delimitation model was defined from consensus across methods and the low number of singletons, MOTUs composed of only one sequence. Genetic distances within and between MOTUs were estimated using MEGA 7.0 (Tamura et al., 2013) based on the K2P evolution model, with 1,000 replicates bootstraps. To elucidate relationships between haplotypes, we also reconstructed a haplotype network using PopART v. 1.7 (Leigh and Bryant, 2015) through the median-joining distance method (Bandelt et al., 1999).

To comprehend which historical processes were responsible for MOTUs diversification in the cis-Andean Rhamdia genus, we estimated divergence time and associated changes in hydrogeological landscapes. The divergence time analysis was also estimated in BEAST v.2.5.2 using a fossil record. Because there is no fossil record for the Rhamdia or its family (Heptapiteridae), calibration points were chosen based on taxa from Pimelodidae: Phractocephalus hemioliopterus (Lundberg and Aguilera, 2003) and Steindachneridion iheringi (Hardman and Lundberg, 2006). Therefore, we added to our dataset sequences of $P$. hemioliopterus, $S$. scriptum, and $S$. parahybae from the BOLD system (Table S1). We placed the fossils as a most recent common ancestor - MRCA - of each genus (crown-group). We set the calibration points with lognormal priors. Specifically, for P. hemioliopterus, we implemented an offset to 9 Mya, with a mean of 0.2 and standard deviation of 1.25 (95\%: 9.11 - 18.5 Mya), while for Steindachneridion clade, the offset was 22 Mya, with mean 0.2 and standard deviation of 1.2 (95\%: $22.2-30.8$ Mya). The Bayesian topology was performed following the same parameters described for the GMYC analysis. The mean and $95 \%$ highest posterior density (HPD) estimates of divergence times and inferred clades' posterior probabilities were visualized using the software FigTree v.1.3.1 (http:// tree.bio.ed.ac.uk/software/figtree/).

\section{Results}

This study's barcode sequences showed more than 550 base pairs (only MNCE was removed because it showed 465 pb). Stop codons, insertions, or deletions were not observed. After alignment and edition, the final matrix had 652 characters, of which 500 positions were conserved, 152 were variable, and 122 were parsimony-informative sites. The sequences of the Jequitinhonha River basin (Code JEQUI) were not added to the dataset, because in Pugedo et al. (2016), the sequences are interspersed among other genera, such as Pimelodella, Steindachneridion, and Colossoma. Considering this situation and the complexity of the Rhamdia genus, we chose not to use these data. However, we present an additional tree (Figure $\mathrm{S} 1$ ), generated with the code sequences JEQUI and RDOCE.

The likelihood of the GMYC model in the species delimitation approach was significantly superior $(\mathrm{L}=319.5186)$ than the likelihood of the null model $\left(\mathrm{L}_{0}=300.0984, \mathrm{p}<0.000\right)$, rejecting the null hypothesis that all individuals belong to a single MOTU. The GMYC model determined 16 MOTUs (confidence interval, 15-48). As expected, the $R$. quelen complex from cis-Andean basins was polyphyletic. The species is represented by more than one MOTU ( 7 MOTUs widely distributed in major cis-Andean basins of South America MOTUs 1, 2, 5, 6, 7, 8 and 9), flagging the presence of cryptic species or a severe taxonomic problem (Figure 2A). The endemic species from the Iguaçu River (R. voulezi and $R$. branneri) were composed of one MOTU each, respectively, MOTUs 3 and 4. Although the latter also have specimens identified as $R$. quelen, probably they represent misidentifications, once $R$. branneri was recognized by molecular and morphological analysis (Garavello and Shibatta, 2016; Ribolli et al., 2017). In the haplotype network analysis, all estimated Rhamdia MOTUs from the Cis-Andean region are well-separated in distinct haplogroups (Figure 2B). Among Mesoamerican species, only $R$. guatemalensis was represented by one MOTU. Rhamdia quelen (named Rhamdia Mesoamerican 1 and 2) and $R$. laticauda showed a hidden genetic diversity that also needs to be assessed. However, because the sampling was small, we will not focus on this issue in the present study.

The estimated OT of the cis-Andean dataset was $0.91 \%$. Ten MOTUs were identified using the OT value as a barcode threshold in jMOTU software. The OT showed congruence with GMYC analysis for cis-Andean MOTUs, except for MOTU Ucayali (two specimens from Ucayali basin), which break-up into two MOTUs forming singletons. The BIN results revealed six molecular units: AAA6222 (correspondent to MOTUs 1 and 2), AAA6323 (MOTUs 3 and 5), ACF1690 (MOTU 4), ACK2037 (MOTU 6), ACF6906 (MOTU7), and AAA6314 (MOTU 8) (see Figure 2A). The sequences from GenBank (code KU, from Paraguay Basin) do not have a BIN.

GMYC results was considered the best species delimitation model based on congruence among different methods and a low number of singletons. The mean intraMOTUs genetic distances were lower than the optimum threshold $(0.91 \%)$, while all mean inter-MOTUs genetic distances were higher than the threshold. These results were expected by DNA barcoding analysis and supporting the MOTUs estimated by GMYC analysis (Table 1).

The phylogenetic gene tree strongly supported almost all relationships among MOTUs (Figure 2A). Two main clades were observed in the Rhamdia genus: one composed of MOTUs from Mesoamerica basins, and the other comprised MOTUs from cis-Andean basins. The cis-Andean clade contains two 
principal groups: The Northwest clade that corresponds to the MOTUs from Amazon, Essequibo, Paraguay, and Itapecuru basins, and the Southeast clade composed of Eastern Brazilian shield basins (Paraná, Uruguay, Iguaçu and São Francisco) plus eastern coastal basins.

The Southeast clade is also subdivided into two main groups well-supported: specimens from Upper Paraná/Upper and Middle Uruguay/São Francisco Basins (named here as MOTU 1) and from Itajaí-Açu basin (MOTU 2); and others composed by valid species from Iguaçu River (MOTU 3 and 4, $R$. voulezi and $R$. branneri respectively), and Paraíba do Sul (MOTU 5 - specimens from Paraíba do Sul and Mucuri rivers). The MOTU 3 also comprises individuals from Iguaçu and Peri Lagoon (Coastal Lagoon in Santa Catarina Island) basins, while MOTU 4 clade corresponds to individuals from Iguaçu, Itapocu, and Lower Paraná basins.

The Northwest clade comprises four MOTUs: individuals from Ucayali River, Upper Amazon basin (MOTU 6), specimens from Itapecuru river, Maranhense Gulf(MOTU 7), individuals from Barama River, Essequibo basin (MOTU 8), and specimens from Paraguay River basin (MOTU 9; Figure 2A).

The time divergence analysis suggests that the diversification processes in the Rhamdia genus began in the Eocene (Figure 2A, Figure S2). The Rhamdia genus' most recent common ancestor (MRCA) was placed in 39.55 million years ago $(95 \% \mathrm{HPD}=18.8-63.7$ million years ago, Mya) and represents the split between cis- and trans-Andean clades. The MRCA cis-Andean MOTUs were dated at 19.2 Mya (95\% $\mathrm{HPD}=9.1-31.9$ Mya) during Middle Miocene. All remaining diversification processes among cis-Andean MOTUs happened during the Miocene-Pleistocene epochs (Figure 2A).

\section{Discussion}

\section{Molecular species delimitation of Rhamdia genus: underestimation diversity in the species complex}

In our study, the species delimitation approach based on molecular data revealed a hidden diversity in the Rhamdia quelen complex. The results support the presence of at least six lineages from cis-Andean hydrographic basins depending on the used species delimitation approach (distance or phylogenetic and coalescent methods). Considering our parameters to choose the best species delimitation model and the phylogenetic species concept based on monophyly (Rosen, 1978), the BIN result (six MOTUs) was discarded. Although the OT also uses a clustering approach based on genetic distance, the high threshold employed by BIN (2.2\% - Ratnasingham and Hebert, 2013) merges four allopatric MOTUs into two groups (AAA6322: MOTU 1 and 2; AAA6323: MOTU 3 and 5). The mean genetic distance above the OT between the clustered MOTUs (1 and 2; 3 and 5) flags that the BIN method underestimated the divergence of Rhamdia lineages. In future studies, its use as a species delimitation method for Rhamdia needs to be carefully evaluated.

The GMYC and distance analysis based on OT showed congruent results, except for specimens from Ucayali. According to the distance analysis (OT), each specimen represents one different MOTU. Talavera et al. (2013) argue that the presence of a high number of singletons could considerably reduce the result's biological meaningfulness. Thus, we view this result as unlikely for now, but it is necessary to ascertain the presence of Rhamdia divergent lineages from the Amazonas region.

The GMYC has been used in numerous empirical studies (Machado et al., 2017; Ramirez et al., 2017, 2020; Melo et al., 2018), and simulation and empirical data suggest that the method is robust to different assumptions (Esselstyn et al., 2012; Reid and Carstens, 2012; Talavera et al., 2013). The method detected nine lineages from cis-Andean hydrographic basins in the present study: two belong to valid species $R$. voulezi and $R$. branneri, and seven divergence lineages currently identified as $R$. quelen. Indeed, many species must be unknown within the $R$. quelen species complex given the wide genus distribution.

Besides the cryptic diversity issue in $R$. quelen complex, we also observed a misidentification problem. Some specimens

Table 1 - The mean intra-MOTU (in bold) and inter-MOTU genetic distances of Rhamdia lineages are based on the COI gene and the K2P model. Values are presented in percentage. UPUSF (Upper Paraná-Uruguay-São Francisco basins); IPLII (Iguaçu ( $R$. voulezi)-Peri Lagoon-Itapocu); ILPI (Iguaçu ( $R$. branneri)-Lower Paraná-Itapocu); MOTU Mesoamerican (MOTU Mesoamerican 1 and Mesoamerican 2).

\begin{tabular}{|c|c|c|c|c|c|c|c|c|c|c|c|c|c|c|}
\hline & & 1 & 2 & 3 & 4 & 5 & 6 & 7 & 8 & 9 & 10 & 11 & 12 & 13 \\
\hline \multirow{9}{*}{ 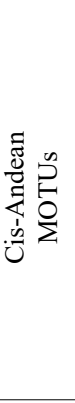 } & 1. MOTU 1 (UPUSF) & 0.33 & & & & & & & & & & & & \\
\hline & 2. MOTU 2 (Itajaí-Açu) & 1.24 & 0.10 & & & & & & & & & & & \\
\hline & 3. MOTU 3 (IPLII) & 2.99 & 2.25 & 0.23 & & & & & & & & & & \\
\hline & 4. MOTU 4 (ILPI) & 3.90 & 3.13 & 1.48 & 0.04 & & & & & & & & & \\
\hline & 5. MOTU 5 (Paraíba do Sul) & 2.87 & 2.91 & 1.25 & 1.74 & 0.27 & & & & & & & & \\
\hline & 6. MOTU 6 (Ucayali) & 5.46 & 5.26 & 4.53 & 5.30 & 4.72 & 0.93 & & & & & & & \\
\hline & 7. MOTU 7 (Itapecuru) & 4.85 & 4.87 & 4.07 & 4.67 & 3.98 & 2.59 & 0.69 & & & & & & \\
\hline & 8. MOTU 8 (Essequibo) & 5.87 & 5.43 & 4.70 & 5.47 & 4.89 & 2.52 & 2.32 & 0.00 & & & & & \\
\hline & 9. MOTU 9 (Paraguay) & 5.77 & 5.27 & 3.51 & 3.96 & 3.95 & 4.16 & 3.31 & 4.16 & 0.00 & & & & \\
\hline \multirow{4}{*}{ 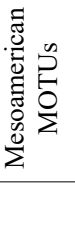 } & 10. MOTU Mesoamerican & 10.10 & 10.19 & 9.30 & 10.24 & 9.12 & 9.42 & 9.63 & 9.47 & 8.46 & 1.65 & & & \\
\hline & 11. R. laticauda & 9.85 & 9.84 & 8.82 & 9.37 & 8.50 & 9.48 & 9.69 & 9.48 & 8.94 & 8.48 & 2.32 & & \\
\hline & 12. R. guatemalensis & 9.25 & 9.28 & 8.40 & 8.98 & 7.76 & 8.96 & 9.42 & 10.11 & 7.64 & 3.15 & 8.20 & 0.11 & \\
\hline & 13. Pimelodella sp. & 12.38 & 11.98 & 10.87 & 11.31 & 11.21 & 11.88 & 11.76 & 11.14 & 10.78 & 13.47 & 11.59 & 12.88 & - \\
\hline
\end{tabular}




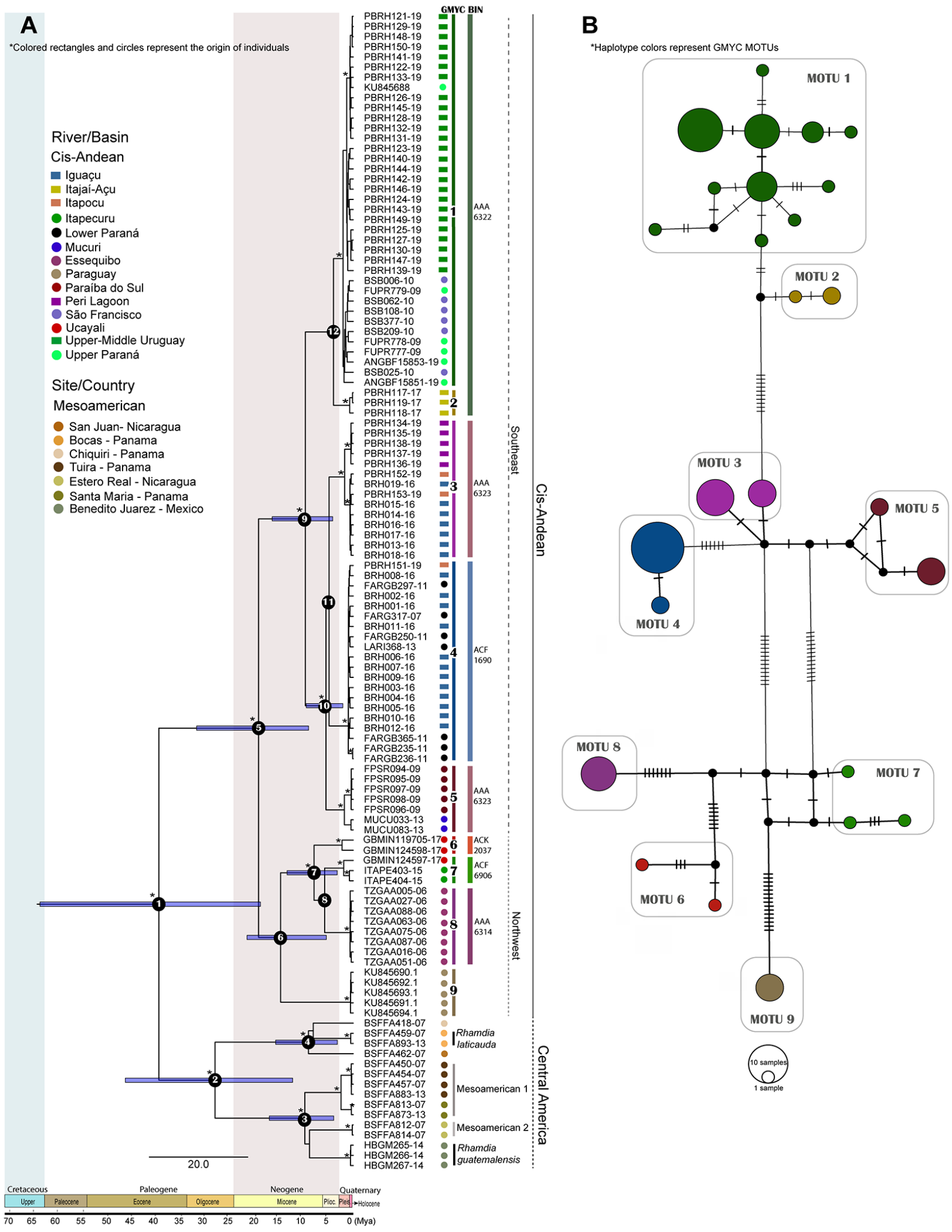

Figure 2 - Time-calibrated topology of Mesoamerica and cis-Andean Rhamdia with species delimitation analyses (A) and median-joining haplotype network for cis-Andean Rhamdia (B) based on COI sequences. Node numbers represent the diversification events, and asterisks represent posterior probabilities above 0.9. Circles represent samples from BOLD System (http://www.boldsystems.org/), while squares are sequences obtained in this study. In the haplotype network, the circle size is proportional to the number of sequences. There is not sharing haplotypes among MOTUS. Black circles indicate haplotypes not sampled. 
from the BOLD system (PBRH, BRH FARG, and LARI projects) were taxonomically identified as $R$. quelen, however, they were clustered with Iguaçu River species $(R$. voulezi and $R$. branneri), forming well-defined and monophyletic MOTUs. Although $R$. branneri and $R$. voulezi are considered endemic to the Iguaçu River, our results corroborate with Ríos et al. (2020), indicating that these species' distribution area may be expanded, with a need for a review of the taxonomic status of both species. Given our results, the revision by Silfvergrip (1996) of the Rhamdia is not appropriate to recover $R$. quelen as a natural unit in terms of species phylogenetic concept.

With rare exceptions (e.g., Iguaçu River basin), we observed that $R$. quelen lineages are specifics from each hydrographic system, i. e., they are not occurring in sympatry. Because these basins were separated a long time ago, the allopatric distribution could reinforce the hypothesis that these lineages represent potential species. Thus, we flag seven independent evolutionary lineages that require further analysis, mainly based on morphological and molecular data, to test the recognition of valid species.

\section{Allopatric events played an essential role in the lineages diversification processes}

The origin and maintenance of the tremendous Neotropical ichthyofauna diversity result from significant historical changes experimented by the continent in the last 90 Mya. The uplift of the Andes and other geological structures, river course changes, and repeated marine incursions and regressions have produced numerous allopatric diversifications in freshwater fishes based on vicariance and geodispersion events (Albert and Reis, 2011). In the following, we will discuss how these events were fundamental to the Rhamdia lineages' divergence.

In our dating analysis, the first diversification event corresponded to the divergence between cis-Andean and Mesoamerican lineages (node 1 - Figure 2A). According to Perdices et al. (2002), Mesoamerican linages resulted from trans-Andean populations' geodispersion events, already differentiated from the cis-Andean portion, which was promoted after the formation of the Isthmus of Panama. Although this node is calibrated, gaps in Rhamdia sampling can lead to our misinterpretation. Rhamdia samples from Colombian trans-Andean basins (e.g., Magdalena basin) would give better results about the diversification process of Rhamdia MRCA that was probably present in the paleoAmazonas-Orinoco basin.

In the cis-Andean clade, the first cladogenetic event (node 5 - Figure 2A) correspond to the divergence between the Northwest group (lineages from Amazonas, Essequibo and Paraguay, and Maranhense Gulf) and Southeast group (Upper and Lower Paraná, Upper and Middle Uruguay, Iguaçu, São Francisco, and coastal basins). This split was dated at 19.2 Ma (95\% HPD = 9.1-31.9 Mya) and could be related to successive geodispersion events from paleo-Amazonas-Orinoco (possible ancestral region) to Paleo-Paraná (Brazilian Shield basins).

Within the Northwest clade, our analysis suggests a cladogenetic event to have happened 14.8 Mya (95\% HPD =5.5-21.6), splitting the MOTU Paraguay and MOTUs from Essequibo, Ucayali (Amazon), and Itapecuru (Maranhense Gulf) basins (Node 6 - Figure 2A). The lineage from the Paraguay basin (MOTU Paraguay), although part of the La Plata basin, was very divergent from the lineages of its main forming rivers (e.g., Paraná, Iguaçu, Uruguay). The mean genetic distance between them was $5.77 \%$ (Table 1), values corresponding to species level differentiation for Neotropical fish (Usso et $a l .$, 2019). The differentiation of MOTU Paraguay from the MRCA Northwest clade probably was through a geodispersal event from northwestern South America to Paleo-Paraguay. The aquatic fauna exchanges between these paleobasins are commonly reported in various fish groups (Montoya-Burgos, 2003; Sivasundar et al., 2001; Tagliacollo et al., 2015) and was possible until the emergence of an impermeable barrier (Michicola Arch, 10 Ma - Lundberg, 1998).

This clade's next diversification process occurred between Ucayali (Amazon), Essequibo basin, and Maranhense Gulf. The cladogenesis was dated at 7.97 Mya (95\% HPD $=3.3-13.5$, Node 7 - Figure $2 \mathrm{~A}$ ) and may have been caused by allopatric diversification. It is not possible to conclude whether the promoter event was vicariance (the ancestor spread throughout the northwest region of the continent and was isolated in the Essequibo basin with the reconfiguration of the current drainage system, which led to the modern lineage) or geodispersion (only after reconfiguration of the drainage system the ancestor reached the Essequibo basin). The first proposal seems to be more plausible since the Essequibo basin's geological history shows connections with both the Orinoco and the Amazon (Branco River) basins (Lujan and Armbruster, 2011).

The split between the MOTUs Itapecuru and Essequibo (Node 8 - Figure 2A), although unsupported (posterior probability $<0.90$ ), is probably resulted from a geodispersion event. The divergence may be related to the low sea level during the Miocene-Pliocene that allowed the ichthyofauna to geodisperse among coastal palaeodrainages. This pattern is observed in Hypostomus (Montoya-Burgos, 2003), Serrasalmus (Hubert et al., 2007), and Salminus species (Machado et al., 2018).

The phylogenetic pattern observed in the Southeast clade is typical in multiple geodispersion events caused by headwater captures or marine regressions, both recurrent in the Brazilian Shield basins and coastal region during the Plio-Pleistocene (Tagliacollo et al., 2015; Thomaz et al., 2015). Our analysis placed the MRCA of MOTU 1 (widely distributed in Upper Paraná, Uruguay, and São Francisco basins) and MOTU 2 from Itajaí-Açu basin nearly at 4 Mya $(95 \%$ HPD $=1.5$ 6.96). The diversification process between them is probably associate with the erosion of the Serra Geral escarpment, a water divider among three hydrographic basins of southern Brazil: Itajaí-Açu, Paraná (Iguaçu), and Uruguay. According to Sordi (2018), the differential erosion by the Itajaí-Açu river lowered the relief allowing the headwater captures belonging to the inland hydrographic basins (Paraná and Uruguay). This episode allowed the ancestor (node 12 - Figure 2A) to geodisperse into the Itajaí-Açu region.

Finally, the clade formed by MOTU Paraíba do Sul and the $R$. branneri and $R$. voulezi species, whose ancestor is located at node 10 (Figure 2A), has a complex diversification history based on the reorganization of hydrogeological systems resulting from tectonic reactivations and sea-level 
oscillations. With specimens inhabiting inland (Iguaçu and Lower Paraná) and coastal (North (Paraíba do Sul and Mucuri) and Southern (Itapocu and Lagoa do Peri) coastal) basins (Figure S1), the non-monophyletic distribution pattern in the Bayesian topology reinforce successive geodispersion events (Figure 2A). There are two possible scenarios to explain the diversification processes based on geodispersion events. The first one involves changes in the Iguaçu paleo-river route, which possessed an eastward draining direction (towards the Atlantic Ocean - Albert and Carvalho, 2011). According to the last glacial maximum model proposed by Thomaz et al. (2015), paleoconnections between basins due to low sea level played an essential role in the dispersion of specimens between Brazilian coastal basins, which would explain our data. Probably, the colonization of this region occurred only with the establishment of the current course of Iguaçu to the Middle/Upper Paraná River, as observed for the Crenicichla lacustris species complex (Piálek et al., 2012).

Another possible diversification scenario of these three lineages encompasses the diversification events postredirection of the Iguaçu River course. At least two events may have occurred: the headwater capture from Iguaçu River to coastal basins (Itapocu basin) followed by dispersal routes via coastal paleodrainages.

\section{Conclusions}

Vicariance and geodispersion events played a crucial role in the current intricate distribution pattern of Rhamdia lineages from the cis-Andean region, and the interaction between these events likely formed the lineage diversity of this genus. Although not all cis-Andean basins were sampled, the results corroborate that $R$. quelen is a species complex and comprises at least seven potential new species that must be taxonomically analyzed to assess whether they will be recovered or described. Despite the tremendous genetic differentiation between the different lineages, the Rhamdia species have similarities in body shape and color pattern, making the identification by non-specialists difficult. The lineages delimitation in the different basins allows minimizing identification errors, avoiding unintentional crossing between species, which may occur with restocking and aquaculture activities since it is a species target for fishery and widely cultivated in southern Brazil, Uruguay and Argentina. Beyond that, it also provides a broad picture of the Rhamdia complex distribution in the Neotropical region.

\section{Acknowledgements}

JR and CBM thanks PNPD/CAPES; EZF thanks CNPq (Grant 304949/2017-5), OAS thanks CNPq (Grant $303685 / 2018-2)$. We thank the Laboratory of Developmental Physiology and Plant Genetics (LFDGV-UFSC) for laboratory facilities. This study was financed in part by the Coordenação de Aperfeiçoamento de Pessoal de Nível Superior - Brasil (CAPES) - Finance Code 001.

\section{Conflict of Interest}

The authors declare that there is no conflict of interest that could be perceived as prejudicial to the impartiality of the reported research.

\section{Author contributions}

RJ, ZFE and MCB conceptualized the study; RJ and SOA curated the data; RJ, SBMS and MCB performed the formal analysis; ZFE supervised the study and provided resources; RJ, SOA and MCB wrote the original draft of the manuscript; all authors participated in the revision and editing of the manuscript and approved the final version.

\section{References}

Agapow PM, Bininda-Emonds OR, Crandall KA, Gittleman JL, Mace GM, Marshall JC and Purvis A (2004) The impact of species concept on biodiversity studies. Q Rev Biol 79:161-179.

Albert JS and Carvalho TP (2011) Neogene assembly of modern faunas. In: Albert JS, Reis RE (eds) Historical biogeography of neotropical freshwater fishes. University of California Press, Berkeley, pp 119-136.

Albert JS and Reis R (2011) Historical biogeography of Neotropical freshwater fishes. University of California Press, Berkeley, $424 \mathrm{p}$.

Albert JS, Tagliacollo VA and Dagosta F (2020) Diversification of Neotropical freshwater fishes. Annu Rev Ecol Evol Syst 51:27-53.

Aljanabi SM and Martinez I (1997) Universal and rapid salt-extraction of high-quality genomic DNA for PCR-based techniques. Nucleic Acids Res 25:4692-4693.

Angrizani RC and Malabarba LR (2018) Morphology and molecular data reveal the presence of two new species under Rhamdia quelen (Quoy Gaimard, 1824) (Siluriformes: Heptapteridae) species complex. Zootaxa 4388:44-60.

Bandelt H, Forster P and Röhl A (1999) Median-Joining networks for inferring intraspecific phylogenies. Mol Biol Evol 16:37-48.

Battisti EK, Rabaioli A, Uczay J, Sutili FJ and Lazzari R (2020) Effect of stocking density on growth, hematological and biochemical parameters and antioxidant status of silver catfish (Rhamdia quelen) cultured in a biofloc system. Aquaculture 524:735213.

Bellafronte E, Mariguela TC, Pereira LHG, Oliveira C and MoreiraFilho O (2013) DNA barcode of Parodontidae species from the La Plata river basin-applying new data to clarify taxonomic problems. Neotrop Ichthyol 11:497-506.

Bichuette ME and Trajano E (2005) A new cave species of Rhamdia (Siluriformes: Heptapteridae) from Serra do Ramalho, northeastern Brazil, with notes on ecology and behavior. Neotrop Ichthyol 3:587-595.

Bickford D, Lohman DJ, Sodhi NS, Ng PKL, Meier R, Winker K, Ingram KK and Das I (2007) Cryptic species as a window on diversity and conservation. Trends Ecol Evolut 22:148-155.

Bortolus A (2008) Error cascades in the biological sciences: the unwanted consequences of using bad taxonomy in ecology. AMBIO J Hum Environ 37:114-119.

Bouckaert R, Heled J, Kühnert D, Vaughan T, Wu C, Xie D, Suchard MA, Rambaut A and Drummond AJ (2014) BEAST 2: a software platform for Bayesian evolutionary analysis. PLoS Comput Biol 10:e1003537.

Brown SD, Collins RA, Boyer S, Lefort MC, Malumbres-Olarte JAGOBA, Vink CJ and Cruickshank RH (2012) Spider: an $\mathrm{R}$ package for the analysis of species identity and evolution, with particular reference to DNA barcoding. Mol Ecol Res 12:562-565.

Cooke GM, Chao NL and Beheregaray LB (2012) Divergent natural selection with gene flow along major environmental gradients in Amazonia: insights from genome scans, population genetics and phylogeography of the characin fish Triportheus albus. Mol Ecol 21:2410-2427.

Dagosta FC and De Pinna M (2019) The fishes of the Amazon: distribution and biogeographical patterns, with a comprehensive list of species. Bull Am Mus Nat Hist 431:1-163. 
Darriba D, Taboada GL, Doallo R and Posada D (2012) jModelTest 2: more models, new heuristics and parallel computing. Nat Methods 9:772.

DoNascimiento C, Provenzano F and Lundberg JG (2004) Rhamdia guasarensis (Siluriformes: Heptapteridae), a new species of cave catfish from the Sierra de Perijá, northwestern Venezuela. Proc Biol Soc Wash 117:564-574.

Esselstyn JA, Evans BJ, Sedlock JL, Anwarali Khan FA and Heaney LR (2012) Single-locus species delimitation: a test of the mixed Yule-coalescent model, with an empirical application to Philippine round-leaf bats. Proc Biol Sci 279:3678-3686.

Frankham R, Ballou JD, Dudash MR, Eldridge MD, Fenster CB, Lacy RC, Mendelson JR, Porton IJ, Ralls K and Ryder OA (2012) Implications of different species concepts for conserving biodiversity. Biol Conserv 153:25-31.

Fujisawa T and Barraclough TG (2013) Delimiting species using single-locus data and the Generalized Mixed Yule Coalescent approach: a revised method and evaluation on simulated data sets. Syst Biol 62:707-724.

Garavello JC and Shibatta OA (2016) Reappraisal of Rhamdia branneri Haseman, 1911 and R. voulezi Haseman, 1911 (Siluriformes: Heptapteridae) from the rio Iguaçu with notes on their morphometry and karyotype. Neotrop Ichthyol 14: e140111.

Gomes LC, Golombieski JI, Chipari-Gomes ARC and Baldisserotto B (2000) Biologia do jundiá Rhamdia quelen (Teleostei, Pimelodidae) Cienc Rural 30:179-185.

Hardman M and Lundberg JG (2006) Molecular phylogeny and a chronology of diversification for "phractocephaline" catfishes (Siluriformes: Pimelodidae) based on mitochondrial DNA and nuclear recombination activating gene 2 sequences. Mol Phylogenet Evol 40:410-418.

Hebert PD, Ratnasingham S and De Waard JR (2003) Barcoding animal life: cytochrome c oxidase subunit 1 divergences among closely related species. Proc R Soc Lond 270:S96-S99.

Hebert PD, Stoeckle MY, Zemlak TS and Francis CM (2004) Identification of birds through DNA barcodes. PLOS Biol 2:e312.

Hubert N and Renno JF (2006) Historical biogeography of South American freshwater fishes. J Biogeogr 33:1414-1436.

Hubert N, Duponchelle F, Nunez J, Garcia-Davila C, Paugy D and Renno JF (2007) Phylogeography of the piranha genera Serrasalmus and Pygocentrus: implications for the diversification of the Neotropical ichthyofauna. Mol Ecol $16: 2115-2136$

Ittzés I, Kronbauer EC, Szabó T, Horváth L, Urbányi B and Müller T (2020) Propagation of jundia Rhamdia quelen (Siluriformes: Heptapteridae) by applying the ovarian sperm injection method. Aquac Rep 16:100275.

Jones M, Ghoorah A and Blaxter M (2011) jMOTU and taxonerator: turning DNA barcode sequences into annotated operational taxonomic units. PLoS One 6:e19259.

Kearse M, Moir R, Wilson A, Stones-Havas S, Cheung M, Sturrock S, Buxton S, Cooper A, Markowitz S, Duran C et al. (2012) Geneious Basic: an integrated and extendable desktop software platform for the organization and analysis of sequence data. Bioinformatics 28:1647-1649.

Koerber S and Reis RE (2020) Evidence for the true type-locality of Rhamdia quelen (Siluriformes: Heptapteridae), and the geographical origin and invalid neotype designation of four of its synonyms. Neotrop Ichthyol 18:e190117.

Leigh JW and Bryant D (2015) PopART: Full-feature software for haplotype network construction. Methods Ecol Evol 6:1110-1116.

Lis JT (1980) Fractionation of DNA fragments by polyethylene glycol induced precipitation. Methods Enzymol 65:347-353.
Lujan N and Armbruster JW (2011) The Guiana Shield. In: Albert JS and Reis RE (eds). Historical biogeography of neotropical freshwater fishes the guiana shield. University of California Press, Berkeley, pp 212-224.

Lundberg JG (1998) The temporal context for the diversification of Neotropical fishes. In: Malabarba R, Reis RE, Vari RP, Lucena ZMS and Lucena CAS (eds) Phylogeny and Classification of Neotropical fishes. EDIPUCRS, Porto Alegre, pp 49-68.

Lundberg JG and Aguilera O (2003) The late Miocene Phractocephalus catfish (Siluriformes: Pimelodidae) from Urumaco, Venezuela: additional specimens and reinterpretation as a distinct species. Neotrop Ichthyol 1:97-109.

Machado CB, Galetti Jr PM and Carnaval AC (2018) Bayesian analyses detect a history of both vicariance and geodispersal in Neotropical freshwater fishes. J Biogeogr 45:1313-1325.

Machado CDB, Ishizuka TK, Freitas PDD, Valiati VH and Galetti Jr PM (2017) DNA barcoding reveals taxonomic uncertainty in Salminus (Characiformes). Syst Biodivers 15:372-382.

Maclaurin J and Sterelny K (2008) What is biodiversity? University of Chicago Press, Chicago, $224 \mathrm{p}$.

Melo BF, Dorini BF, Foresti F and Oliveira C (2018) Little divergence among mitochondrial lineages of Prochilodus (Teleostei, Characiformes). Front Genet 9:107

Melo BF, Sidlauskas BL, Hoekzema K, Frable BW, Vari RP, Oliveira C (2016) Molecular phylogenetics of the Neotropical fish family Prochilodontidae (Teleostei: Characiformes). Mol Phylogenet Evol 102:189-201.

Monaghan MT, Wild R, Elliot M, Fujisawa T, Balke M, Inward DJG, Lees DC, Ranaivosolo R, Eggleton P, Barraclough TG et al. (2009) Accelerated species inventory on Madagascar using coalescent-based models of species delineation. Syst Biol 58:298-311

Montoya-Burgos JI (2003) Historical biogeography of the catfish genus Hypostomus (Siluriformes: Loricariidae), with implications on the diversification of Neotropical ichthyofauna. Mol Ecol 12:1855-1867.

Perdices A, Bermingham E, Montilla A and Doadrio I (2002) Evolutionary history of the genus Rhamdia (Teleostei: Pimelodidae) in Central America. Mol Phylogenet Evol 25:172-189.

Pereira LH, Hanner R, Foresti F and Oliveira C (2013) Can DNA barcoding accurately discriminate megadiverse Neotropical freshwater fish fauna? BMC Genet 14:20.

Piálek L, Říčan O, Casciotta J, Almirón A and Zrzavý J (2012) Multilocus phylogeny of Crenicichla (Teleostei: Cichlidae), with biogeography of the C. lacustris group: species flocks as a model for sympatric speciation in rivers. Mol Phylogenet Evol 62:46-61.

Pons J, Barraclough TG, Gomez-Zurita J, Cardoso A, Duran DP, Hazell S, Kamoun S, Sumlin WD and Vogler AP (2006) Sequence-based species delimitation for the DNA taxonomy of undescribed insects. Syst Biol 55:595-609.

Pugedo ML, de Andrade Neto FR, Pessali TC, Birindelli JLO and Carvalho DC (2016) Integrative taxonomy supports new candidate fish species in a poorly studied neotropical region: the Jequitinhonha River Basin. Genetica 144:341-349.

Ramirez J L, Santos, CA, Machado CB, Oliveira AK, Garavello JC, Britski HA and Galetti Jr PM (2020) Molecular phylogeny and species delimitation of the genus Schizodon (Characiformes, Anostomidae). Mol Phylog Evol 153:106959.

Ramirez JL, Birindelli JL, Carvalho DC, Affonso PRAM, Venere PC, Ortega H, Carrilo-Avila M, Rodríguez-Pulido JA and Galetti Jr PM (2017) Revealing hidden diversity of the underestimated neotropical ichthyofauna: DNA barcoding in the recently described genus Megaleporinus (Characiformes: Anostomidae). Front Genet 8:149. 
Ratnasingham S and Hebert PDN (2013) A DNA-based registry for all animal species: The Barcode Index Number (BIN) System. PLoS One 8:e66213.

Reid NM and Carstens BC (2012) Phylogenetic estimation error can decrease the accuracy of species delimitation: a Bayesian implementation of the general mixed Yule-coalescent model. BMC Evol Biol 12:196.

Reis RE, Albert JS, Di Dario F, Mincarone MM, Petry P and Rocha LA (2016) Fish biodiversity and conservation in South America. J Fish Biol 89:12-47.

Ribolli J, Scaranto BM, Shibatta OA, Bombardelli RA and ZaniboniFilho E (2017) DNA barcoding confirms the occurrence of Rhamdia branneri and Rhamdia voulezi (Siluriformes: Heptapteridae) in the Iguaçu River Basin. Neotrop Ichthyol 15:e160147.

Ríos N, Casanova A, Hermida M, Pardo BG, Martínez P, Bouza C and García G (2020) Population genomics in Rhamdia quelen (Heptapteridae, Siluriformes) reveals deep divergence and adaptation in the Neotropical region. Genes 11:109.

Rosen DE (1978) Vicariant patterns and historical explanation in biogeography. Syst Biol 27:159-188.

Salhia M, Bessonart M, Chediak G, Bellagamba M and Carneiva D (2004) Growth, feed utilization and body composition of black catfish, Rhamdia quelen, fry fed diets containing different protein and energy levels. Aquaculture 231:435-444.

Scaranto BMS, Ribolli J and Zaniboni-Filho E (2018) DNA barcoding reveals blend of silver catfish Rhamdia species from fish farms in Southern Brazil. Aquacul Res 49:1907-1913.

Silfvergrip A (1996) A systematic revision of the Neotropical catfish genus Rhamdia (Teleostei, Pimelodidae). M. Sc. Thesis, Stockholm University, Stockholm.

Sivasundar A, Bermingham E and Ortí G (2001) Population structure and biogeography of migratory freshwater fishes (Prochilodus: Characiformes) in major South American rivers. Mol Ecol 10:407-417.

Sordi MV (2018) Rearranjo fluvial como mecanismo de evolução do relevo em escarpas de margem passiva: Serra Geral Catarinense, Sul do Brasil. M. Sc. Thesis, Universidade Federal de Minas Gerais, Belo Horizonte.

Tagliacollo VA, Rozo FF, Duke-Sylvester SM, Oliveira C and Albert JS (2015) Biogeographical signature of river capture events in Amazonian lowlands. J Biogeogr 42:2349-2363.
Talavera G, Dincă V and Vila R (2013) Factors affecting species delimitations with the GMYC model: insights from a butterfly survey. Methods Ecol Evol 4:1101-1110.

Tamura K, Stecher G, Peterson D, Filipski A and Kumar S (2013) MEGA6: molecular evolutionary genetics analysis version 6.0. Mol Biol Evol 30:2725-2729.

Thomaz AT, Malabarba LR, Bonatto SL and Knowles LL (2015) Testing the effect of palaeodrainages versus habitat stability on genetic divergence in riverine systems: study of a Neotropical fish of the Brazilian coastal Atlantic Forest. J Biogeogr 42:2389-2401

Usso MC, Santos ARD, Gouveia JG, Frantine-Silva W, Araya-Jaime C, Oliveira MLMD, Foresti F, Giuliano-Caetano L and Dias AL (2019) Genetic and chromosomal differentiation of Rhamdia quelen (Siluriformes, Heptapteridae) revealed by repetitive molecular markers and DNA barcoding. Zebrafish 16:87-97.

Ward RD, Zemlak TS, Innes BH, Last PR and Hebert PD (2005) DNA barcoding Australia's fish species. Philos Trans R Soc 360:1847-1857.

\section{Internet resources}

Rambaut A and Drummond AJ (2007) Tracer v.1.4, http://tree.bio. ed.ac.uk/software/tracer/ (accessed 05 September 2019)

\section{Supplementary material}

The following online material is available for this article:

Table S1 - Lineage, taxon, voucher, locality information and BOLD accession numbers of the analyzed specimens of Rhamdia.

Figure S1 - Bayesian inference topology of Rhamdia based on $\mathrm{COI}$ sequences.

Figure S2 - Time-calibrated topology of Rhamdia and outgroups (Pimelodella, Phractocephalus, and Steindachneridion) based on COI sequences.

Associate Editor: Fabrício Rodrigues dos Santos

License information: This is an open-access article distributed under the terms of the Creative Commons Attribution License (type CC-BY), which permits unrestricted use, distribution and reproduction in any medium, provided the original article is properly cited. 